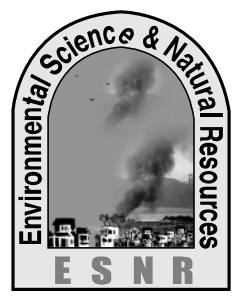

J. Environ. Sci. \& Natural Resources, 6(1): 203 -208, 2013

ISSN 1999-7361

\title{
Feasibility of Replacing Chemical Fertilizer by Using Organic Fertilizer in Wheat (Triticum aestivum) Considering Yield Contributing Characters and Yield
}

\author{
Z. Akhter ${ }^{1}$, M. H. Imam ${ }^{2}$, M. A. Razzak ${ }^{1}$, A. H. M. M. R. AKhter ${ }^{3}$ and M. AKhter ${ }^{4}$ \\ ${ }^{1}$ Department of Agronomy, Sher-E-Bangla Agricultural University \\ ${ }^{2}$ Election Commission Secretariat, Dhaka \\ ${ }^{3}$ Agronomy Division, RARS, Jamalpur \\ ${ }^{4}$ SRDI, District Office, Jamalpur.
}

\begin{abstract}
The experiment comprised of 10 treatments, such as $\mathrm{T}_{0}$ : Control condition; $\mathrm{T}_{1}$ : All chemical fertilizer as recommended dose; $\mathrm{T}_{2}$ : Cowdung as recommended dose; $\mathrm{T}_{3}$ : Compost as recommended dose; $\mathrm{T}_{4}$ : 1/2 Cowdung $+1 / 2$ Compost; $\mathrm{T}_{5}$ : Cowdung + Compost; $\mathrm{T}_{6}$ : Cowdung $+1 / 2$ Chemical fertilizer; $\mathrm{T}_{7}$ : Compost $+1 / 2$ Chemical fertilizer; $\mathrm{T}_{8}$ : Cowdung + Compost $+1 / 2$ Chemical fertilizer and $\mathrm{T}_{9}: 1 / 2$ Cowdung $+1 / 2$ Compost $+1 / 2$ Chemical fertilizer. The experiment was laid out in Randomized Complete Block Design (RCBD) with three replications. Data on different growth characters and yield were recorded. Among the treatments all chemical fertilizers as recommended dose $\left(T_{1}\right)$ and cowdung + compost $+1 / 2$ chemical fertilizer $\left(T_{8}\right)$ were found superior considering all yield contributing characters and yield. At 30 (Days after Sowing) DAS, the longest plant was recorded from $\mathrm{T}_{8}$ $(27.93 \mathrm{~cm})$, while the shortest plant was found in $\mathrm{T}_{0}(23.13 \mathrm{~cm})$. At 50, 70, 90 DAS and harvest the longest plant was recorded from $\mathrm{T}_{1}(52.13 \mathrm{~cm}, 82.13 \mathrm{~cm}, 85.93 \mathrm{~cm}$ and $95.21 \mathrm{~cm})$, whereas the shortest plant was obtained from $\mathrm{T}_{0}(41.14 \mathrm{~cm}, 65.84 \mathrm{~cm}$, $70.77 \mathrm{~cm}$ and $76.00 \mathrm{~cm})$. At 30, 50, 70, 90 DAS and harvest the maximum number of tillers hill ${ }^{-1}$ was recorded from $\mathrm{T}_{1}(2.00$, $5.64,6.93,6.15$ and 5.78), whereas the minimum number was found in $\mathrm{T}_{0}(1.33,2.87,4.20,3.94$ and 3.72). The longest spike $(19.86 \mathrm{~cm})$, maximum number of spikelets spikes ${ }^{-1}(20.33)$, maximum number of filled grains spike ${ }^{-1}$ (34.00), highest grain yield $\left(3.71 \mathrm{t} \mathrm{ha}^{-1}\right)$ and highest straw yield $\left(5.78 \mathrm{t} \mathrm{ha}^{-1}\right)$ was attained from $\mathrm{T}_{1}$ and the shortest spike $(14.33 \mathrm{~cm})$, minimum number of spikelets spikes $^{-1}$ (14.18), minimum number of filled grains spike ${ }^{-1}$ (21.53), lowest grain yield $\left(2.06 \mathrm{t} \mathrm{ha}^{-1}\right)$ and lowest straw yield $\left(4.49 \mathrm{t} \mathrm{ha}^{-1}\right)$ was recorded from $\mathrm{T}_{0}$.
\end{abstract}

Key Words: Chemical fertilizer, Organic fertilizer, Wheat and Yield

\section{Introduction}

Wheat (Triticum aestivum L.) is one of the most important cereal crops followed by rice and it is as well as staple food and has the large acreage among all the field crops in the world (FAO, 2010). About two third of the total world's population consume wheat as staple food (Majumder, 1991). The crop is grown under different environmental condition ranging from humid to arid, subtropical to temperate zone. Dubin and Ginkel (1991) reported that the largest area of wheat cultivation in the warmer climates exists in the South-East Asia including Bangladesh, India and Nepal. In Bangladesh, wheat is the second most important cereal crops that contribute to the national economy by reducing the volume of import of cereals for fulfilling the food requirements of the country (Razzaque et al., 1992). Wheat grain is rich in food value containing $69.60 \%$ carbohydrate, $12.00 \%$ protein, $1.72 \%$ fat $17.20 \%$ and minerals (BARI, 2006). Wheat cultivation has been increased manifolds to meet up the food shortage in the country. The area, production and yield of wheat have been increasing dramatically during the last two decades, but its present yield is too low in comparison to that of some developed countries like Japan, France, Germany and UK producing 3.76, 7.12, 7.28, and $8.00 \mathrm{t} \mathrm{ha}^{-1}$, respectively (FAO, 2000). In Bangladesh, the position of wheat is second in respect of total area
(0.80 million hectares) and production (2.80 million ton) after rice and the average yield is only $3.44 \mathrm{t} \mathrm{ha}^{-1}$ (BBS, 2010) but it can be increased up to $6.8 \mathrm{t} \mathrm{ha}^{-1}$ (RARS, 2010).

Low yield of wheat in Bangladesh, is not an indication of low yielding potentiality of this crop, but may be attributed to a number of reasons, viz., unavailability of quality seeds of high yielding varieties, limitation in adoption of modern and improved agronomic practices, such as optimum seed rate, delay sowing after harvesting transplanted aman rice, judicious application of irrigation, fertilizer management and other inputs. In order to break the above yield barriers, sustain the productivity and obtain sufficiency in food, the overall management system of crop needs to be improved especially through the nutrient management of the crop. Proper utilization of different sources of nutrients in context of crop-soil productivity must be explored for sustaining the productivity. The sources of nutrients for crops are nutrient reserve in soil, organic and inorganic fertilizers. None of the sources is complete and therefore, no one is sufficient to sustain soil fertility and productivity. Combination of organic and inorganic fertilizers is being stressed now-a-days. The application of different fertilizers and manures influences the physical and chemical properties of soil 
and enhance the biological activities. Organic fertilizer enhances soil porosity by increasing regular and irregular pores and causes a priming effect of native soil organic matter. Application of both chemical and organic fertilizers is need for the improvement of soil physical properties and quick supply of essential plant nutrients for higher yield. The combined effect of organic manure and inorganic fertilizer on crop yield was also reported by many workers (Davarynejad et al., 2004; Singh and Singh, 2000).Therefore, objective of this shady was to study the feasibility of replacing chemical fertilizer by organic fertilizer in wheat by yield contributing character yield.

\section{Materials and Methods}

The experiment was conducted to study the feasibility of replacing chemical fertilizer by using organic fertilizer in wheat during the period from October 2010 to March 2011. The experiment comprised the 10 treatments i.e., $\mathrm{T}_{0}$ : Control (without manure and fertilizer); $\quad \mathrm{T}_{1}$ : All chemical fertilizers as recommended dose; $\mathrm{T}_{2}$ : Cowdung as recommended dose; $\mathrm{T}_{3}$ : Compost as recommended dose; $\mathrm{T}_{4}: 1 / 2$ Cowdung + 1/2 Compost; $\mathrm{T}_{5}$ : Cowdung + Compost; $\mathrm{T}_{6}$ : Cowdung $+1 / 2$ Chemical fertilizer; $\mathrm{T}_{7}$ : Compost + $1 / 2$ Chemical fertilizer; $\mathrm{T}_{8}$ : Cowdung + Compost $+1 / 2$ Chemical fertilizer and $\mathrm{T}_{9}: 1 / 2$ Cowdung $+1 / 2$ Compost $+1 / 2$ Chemical fertilizer. Recommended dose of chemical fertilizer, cowdung and compost for this experiment were Urea: $220 \mathrm{~kg} \mathrm{ha}^{-1}$, TSP: $180 \mathrm{~kg} \mathrm{ha}^{-1}$, MP: $50 \mathrm{~kg} \mathrm{ha}^{-1}$, Gypsum: $120 \mathrm{~kg} \mathrm{ha}^{-1}$, Zinc oxide: $5 \mathrm{~kg}$ $\mathrm{ha}^{-1}$, Boric acid: $6 \mathrm{~kg} \mathrm{ha}^{-1}$, Cowdung: 8 ton ha $\mathrm{ha}^{-1}$ and compost: 8 ton ha ${ }^{-1}$. The data obtained for different characters were statistically analyzed to observe the significant difference among the treatment. The mean values of all the characters were calculated and analyses of variance were performed. The significance of the difference among the treatment means was estimated by the Duncan Multiple Range Test (DMRT) at 5\% level of probability (Gomez and Gomez, 1984).

\section{Results and Discussion}

Plant height varied significantly at 30, 50, 70 and 90 DAS, and at harvest for different chemical and organic fertilizer and their combinations under the present trial (Table 1). At 30 DAS, the longest plant $\left(27.93 \mathrm{~cm}\right.$ ) was recorded from $\mathrm{T}_{8}$ (cowdung + compost $+1 / 2$ chemical fertilizer), which was statistically similar with $T_{1}$ (all chemical fertilizer as recommended dose), $\mathrm{T}_{3}$ (compost as recommended dose), $T_{4}\left(1 / 2\right.$ cowdung $+1 / 2$ compost), $T_{5}$ (cowdung + compost), $\mathrm{T}_{6}$ (cowdung $+1 / 2$ chemical fertilizer), $\mathrm{T}_{7}$ (compost $+1 / 2$ chemical fertilizer), $\mathrm{T}_{9}(1 / 2$ cowdung + $1 / 2$ compost $+1 / 2$ chemical fertilizer) and $T_{2}$ (cowdung as recommended dose) $(27.75 \mathrm{~cm}, 27.59 \mathrm{~cm}, 27.54$ $\mathrm{cm}, 27.36 \mathrm{~cm}, 27.28 \mathrm{~cm}, 27.13 \mathrm{~cm}, 26.87 \mathrm{~cm}, 26.59$ $\mathrm{cm}$, respectively), while the shortest plant $(23.13 \mathrm{~cm})$ was obtained from $\mathrm{T}_{0}$ (control condition). At $50 \mathrm{DAS}$, the longest plant $(52.13 \mathrm{~cm})$ was recorded from $T_{1}$, which was statistically similar with $\mathrm{T}_{8}, \mathrm{~T}_{9}, \mathrm{~T}_{7}, \mathrm{~T}_{6}, \mathrm{~T}_{5}$ and $\mathrm{T}_{4}$ treatments and closely followed by $\mathrm{T}_{2}$ and $\mathrm{T}_{3}$, whereas the shortest plant $(41.14 \mathrm{~cm})$ was obtained from $\mathrm{T}_{0}$. At 70 DAS, the longest plant $(82.13 \mathrm{~cm})$ was recorded from $\mathrm{T}_{1}$, which was statistically at per with $\mathrm{T}_{8}, \mathrm{~T}_{9}, \mathrm{~T}_{7}, \mathrm{~T}_{6}, \mathrm{~T}_{5}, \mathrm{~T}_{4}, \mathrm{~T}_{3}$ and $\mathrm{T}_{2}(81.02 \mathrm{~cm}, 78.27 \mathrm{~cm}$, $77.73 \mathrm{~cm}, 77.53 \mathrm{~cm}, 76.07 \mathrm{~cm}, 75.27 \mathrm{~cm}, 74.87 \mathrm{~cm}$ and $74.13 \mathrm{~cm}$, respectively) and the shortest plant $(65.84 \mathrm{~cm})$ was found from $\mathrm{T}_{0}$. At $90 \mathrm{DAS}$, the longest plant $(85.93 \mathrm{~cm})$ was recorded from $\mathrm{T}_{1}$, which was statistically similar with $\mathrm{T}_{8}, \mathrm{~T}_{9}, \mathrm{~T}_{7}, \mathrm{~T}_{6}, \mathrm{~T}_{5}$ and $\mathrm{T}_{4}$ $(83.79 \mathrm{~cm}, 81.60 \mathrm{~cm}, 80.67 \mathrm{~cm}, 80.27 \mathrm{~cm}, 80.13 \mathrm{~cm}$ and $77.87 \mathrm{~cm}$, respectively) and closely followed by $\mathrm{T}_{2}$ and $\mathrm{T}_{3}(75.67 \mathrm{~cm}$ and $75.43 \mathrm{~cm}$, respectively), whereas the shortest plant was recorded from $\mathrm{T}_{0}$ $(70.77 \mathrm{~cm})$. At harvest, the longest plant was attained from $\mathrm{T}_{1}(95.21 \mathrm{~cm})$, which was statistically similar with $\mathrm{T}_{8}, \mathrm{~T}_{9}, \mathrm{~T}_{6}, \mathrm{~T}_{7}, \mathrm{~T}_{5}, \mathrm{~T}_{4}, \mathrm{~T}_{2}$ and $\mathrm{T}_{3}(93.67 \mathrm{~cm}, 90.36$ $\mathrm{cm}, 89.67 \mathrm{~cm}, 89.53 \mathrm{~cm}, 89.05 \mathrm{~cm}, 85.87 \mathrm{~cm}, 84.73$ $\mathrm{cm}$ and $84.36 \mathrm{~cm}$, respectively and the shortest plant $(76.00 \mathrm{~cm})$ was recorded from $\mathrm{T}_{0}$. Application of all chemical fertilizer in recommended doses ensured the essential macro and micro nutrients for the vegetative growth of the wheat and the ultimate results were the longest plant. Combination of cowdung, compost and chemical fertilizers half in recommended doses also created a favorable condition for the growth and development of wheat plant for that combination of cowdung, compost and half chemical fertilizers also gave the similar results. Aga et al. (2004) reported that plant growth characters such as plant height were highest with application of $15 \mathrm{t}$ compost ha $\mathrm{a}^{-1}$. 
Table 1. Effect of chemical and organic fertilizers and their combinations on plant height of wheat

\begin{tabular}{clllll}
\hline Treatment & \multicolumn{5}{c}{ Plant height $(\mathrm{cm}) \mathrm{at}$} \\
\cline { 2 - 6 } & $30 \mathrm{DAS}$ & $50 \mathrm{DAS}$ & $70 \mathrm{DAS}$ & $90 \mathrm{DAS}$ & Harvest \\
\hline $\mathrm{T}_{0}$ & $23.13 \mathrm{~b}$ & $41.14 \mathrm{c}$ & $65.84 \mathrm{~b}$ & $70.77 \mathrm{c}$ & $76.00 \mathrm{~b}$ \\
$\mathrm{~T}_{1}$ & $27.75 \mathrm{a}$ & $52.13 \mathrm{a}$ & $82.13 \mathrm{a}$ & $85.93 \mathrm{a}$ & $95.21 \mathrm{a}$ \\
$\mathrm{T}_{2}$ & $26.59 \mathrm{a}$ & $45.16 \mathrm{bc}$ & $74.13 \mathrm{a}$ & $75.67 \mathrm{bc}$ & $84.73 \mathrm{ab}$ \\
$\mathrm{T}_{3}$ & $27.59 \mathrm{a}$ & $45.06 \mathrm{bc}$ & $74.87 \mathrm{a}$ & $75.43 \mathrm{bc}$ & $84.36 \mathrm{ab}$ \\
$\mathrm{T}_{4}$ & $27.54 \mathrm{a}$ & $46.99 \mathrm{a}-\mathrm{c}$ & $75.27 \mathrm{a}$ & $77.87 \mathrm{a}-\mathrm{c}$ & $85.87 \mathrm{ab}$ \\
$\mathrm{T}_{5}$ & $27.36 \mathrm{a}$ & $48.40 \mathrm{ab}$ & $76.07 \mathrm{a}$ & $80.13 \mathrm{ab}$ & $89.05 \mathrm{a}$ \\
$\mathrm{T}_{6}$ & $27.28 \mathrm{a}$ & $48.66 \mathrm{ab}$ & $77.53 \mathrm{a}$ & $80.27 \mathrm{ab}$ & $89.67 \mathrm{a}$ \\
& $27.13 \mathrm{a}$ & $49.06 \mathrm{ab}$ & $77.73 \mathrm{a}$ & $80.67 \mathrm{ab}$ & $89.53 \mathrm{a}$ \\
$\mathrm{T}_{7}$ & $27.93 \mathrm{a}$ & $51.16 \mathrm{ab}$ & $81.02 \mathrm{a}$ & $83.79 \mathrm{ab}$ & $93.67 \mathrm{a}$ \\
$\mathrm{T}_{8}$ & $26.87 \mathrm{a}$ & $49.33 \mathrm{ab}$ & $78.27 \mathrm{a}$ & $81.60 \mathrm{ab}$ & $90.36 \mathrm{a}$ \\
\hline $\mathrm{SE}$ & 0.866 & 1.96 & 2.75 & 2.67 & 3.40 \\
\hline $\mathrm{CV}(\%)$ & 5.57 & 7.11 & 6.23 & 5.83 & 6.69 \\
\hline
\end{tabular}

In a column, means having similar letter(s) are statistically similar and those having dissimilar letter(s) differ significantly as per 0.05 level of significance. $\mathrm{CV}=\mathrm{Co}$-efficient of Variance.

Statistically significant variation was recorded for number of tillers hill ${ }^{-1}$ at 30, 50, 70 and 90 DAS, and at harvest for different chemical and organic fertilizers and their combinations (Table 2). At 30 DAS, the maximum number of tillers hill ${ }^{-1}$ was recorded from $\mathrm{T}_{1}$ (2.00), which was statistically similar with $\mathrm{T}_{8}, \mathrm{~T}_{9}$, and $\mathrm{T}_{7}(1.87,1.80$ and 1.68 , respectively) and was closely followed by $\mathrm{T}_{4}$ (1.60), whereas the minimum number was found from $\mathrm{T}_{0}$ (1.33), which was statistically similar with $\mathrm{T}_{3}, \mathrm{~T}_{5}$, and $\mathrm{T}_{2}$ (1.40, 1.40 and 1.47 , respectively). At 50 DAS, the maximum number of tillers hill ${ }^{-1}$ was recorded from $\mathrm{T}_{1}$ (5.64), which was statistically at per with $\mathrm{T}_{8}$ (5.47) and closely followed by $\mathrm{T}_{9}$ (5.13), while the minimum number was recorded from $\mathrm{T}_{0}$ (2.87). At 70 DAS, the maximum number of tillers hill $^{-1}$ was recorded from $T_{1}$ (6.93), which was statistically similar with $\mathrm{T}_{8}$ (6.80) and closely followed by $\mathrm{T}_{6}, \mathrm{~T}_{9}$, and $\mathrm{T}_{7}(6.30,6.26$ and 6.23, respectively), again the minimum number was found from $\mathrm{T}_{0}(4.20)$, which was statistically similar with $\mathrm{T}_{2}$ (4.60). At 90 DAS, the maximum number of tillers hill $^{-1}$ was recorded from $\mathrm{T}_{1}(6.15)$, which was statistically similar with $\mathrm{T}_{8} \quad$ (5.67) and closely followed by $\mathrm{T}_{9}(5.47)$, while the minimum number was observed from $\mathrm{T}_{0}$ (3.94), which was statistically similar with $\mathrm{T}_{2}$ and $\mathrm{T}_{3}$ (4.25 and 4.43, respectively). At harvest, the maximum number of tillers hill ${ }^{-1}$ was obtained from $\mathrm{T}_{1}$ (5.78), which was closely followed by $\mathrm{T}_{8}(5.13)$ and the minimum number was recorded from $\mathrm{T}_{0}$ (3.72), which was statistically similar with $\mathrm{T}_{2}, \mathrm{~T}_{3}$ and $\mathrm{T}_{4}(3.87,3.92$ and 4.03 , respectively). It was revealed that all chemical fertilizer as recommended dose produced maximum tillers hill ${ }^{-1}$ at different days after sowing.

Table 2. Effect of chemical and organic fertilizer and their combinations on number of tillers hill ${ }^{-1}$ of wheat

\begin{tabular}{|c|c|c|c|c|c|}
\hline \multirow[t]{2}{*}{ Treatment } & \multicolumn{5}{|c|}{ Number of tillers hill ${ }^{-1}$ at } \\
\hline & 30 DAS & $50 \mathrm{DAS}$ & $70 \mathrm{DAS}$ & $90 \mathrm{DAS}$ & Harvest \\
\hline $\mathrm{T}_{0}$ & $1.33 \mathrm{~d}$ & $2.87 \mathrm{~g}$ & $4.20 \mathrm{e}$ & $3.94 \mathrm{f}$ & $3.72 \mathrm{~g}$ \\
\hline $\mathrm{T}_{1}$ & $2.00 \mathrm{a}$ & $5.64 \mathrm{a}$ & $6.93 \mathrm{a}$ & $6.15 \mathrm{a}$ & $5.78 \mathrm{a}$ \\
\hline $\mathrm{T}_{2}$ & $1.47 \mathrm{~cd}$ & 3.70 ef & $4.60 \mathrm{de}$ & $4.25 \mathrm{ef}$ & $3.87 \mathrm{fg}$ \\
\hline $\mathrm{T}_{3}$ & $1.40 \mathrm{~cd}$ & $3.60 \mathrm{f}$ & $4.73 \mathrm{~d}$ & $4.43 \mathrm{~d}-\mathrm{f}$ & $3.92 \mathrm{fg}$ \\
\hline $\mathrm{T}_{4}$ & $1.60 \mathrm{~b}-\mathrm{d}$ & $3.87 \mathrm{~d}-\mathrm{f}$ & $4.93 \mathrm{~d}$ & $4.60 \mathrm{de}$ & $4.03 \mathrm{e}-\mathrm{g}$ \\
\hline $\mathrm{T}_{5}$ & $1.40 \mathrm{~cd}$ & $4.27 \mathrm{~d}$ & $5.63 \mathrm{c}$ & $4.87 \mathrm{~d}$ & $4.17 \mathrm{~d}-\mathrm{f}$ \\
\hline $\mathrm{T}_{6}$ & $1.52 \mathrm{~b}-\mathrm{d}$ & $4.13 \mathrm{de}$ & $6.30 \mathrm{~b}$ & $5.00 \mathrm{~cd}$ & $4.35 \mathrm{c}-\mathrm{e}$ \\
\hline $\mathrm{T}_{7}$ & $1.68 \mathrm{a}-\mathrm{d}$ & $4.87 \mathrm{c}$ & $6.23 \mathrm{~b}$ & $5.03 \mathrm{~cd}$ & $4.47 \mathrm{~cd}$ \\
\hline $\mathrm{T}_{8}$ & $1.87 \mathrm{ab}$ & $5.47 \mathrm{ab}$ & $6.80 \mathrm{a}$ & $5.67 \mathrm{ab}$ & $5.13 \mathrm{~b}$ \\
\hline $\mathrm{T}_{9}$ & $1.80 \mathrm{a}-\mathrm{c}$ & $5.13 \mathrm{bc}$ & $6.26 \mathrm{~b}$ & $5.47 \mathrm{bc}$ & $4.62 \mathrm{c}$ \\
\hline SE & 0.121 & 0.143 & 0.164 & 0.186 & 0.130 \\
\hline $\mathrm{CV}(\%)$ & 13.03 & 5.67 & 5.04 & 6.51 & 5.15 \\
\hline
\end{tabular}

In a column, means having similar letter(s) are statistically similar and those having dissimilar letter(s) differ significantly as per 0.05 level of significance. $\mathrm{CV}=\mathrm{Co}$-efficient of Variance. 
Statistically significant variation was recorded for number of plants $\mathrm{m}^{-2}$, number of spikes plant ${ }^{-1}$, spike length, number of spikelets spike ${ }^{-1}$ and number of spike $\mathrm{m}^{-2}$ for different chemical and organic fertilizers and their combinations (Table 3). The maximum number of plants $\mathrm{m}^{-2}$ was found in $\mathrm{T}_{1}$ (45.33) which was statistically similar with $\mathrm{T}_{8}, \mathrm{~T}_{9}, \mathrm{~T}_{6}, \mathrm{~T}_{5}, \mathrm{~T}_{7}, \mathrm{~T}_{4}$ and $\mathrm{T}_{3}$ (45.00, 43.67, 43.33, 42.33, 42.00, 41.00 and 39.67 , respectively) and closely followed by $T_{2}$ (37.67), whereas the minimum number was recorded from $\mathrm{T}_{0}$ (32.67). Application of chemical fertilizers in their recommended doses ensured the essential macro and micro nutrients for the plant and the ultimate results were the maximum number of hill in $\mathrm{m}^{-2}$ area. Combination of cowdung, compost and chemical fertilizers half in recommended doses also created a favorable condition for the growth and development of wheat hence this treatment also gave the higher number of plants $\mathrm{m}^{-2}$. The maximum number of spikes plant ${ }^{-1}$ was found in $T_{1}$ (4.61), which was statistically similar with $\mathrm{T}_{8}, \mathrm{~T}_{7}, \mathrm{~T}_{9}, \mathrm{~T}_{6}$ and $\mathrm{T}_{5}$ (4.50, $4.45,4.40,4.29$ and 4.24, respectively) and closely followed by $\mathrm{T}_{4}$ (3.95), while the minimum number from $\mathrm{T}_{0}$ (3.73), which was statistically similar with $\mathrm{T}_{3}$ and $\mathrm{T}_{2}$ (3.74 and 3.86, respectively). The results collaborates with the findings of Tamaki et al. (2002) who observed that continuous organic farming increase in spike number plant $^{-1}$. The maximum number of spikelets spikes ${ }^{-1}$ was recorded from $\mathrm{T}_{1}$ (20.33), which was statistically at per with $\mathrm{T}_{8}, \mathrm{~T}_{9}, \mathrm{~T}_{6}$ and $\mathrm{T}_{7}$ (19.07, 18.33, 17.88 and 17.50, respectively) and followed by $\mathrm{T}_{5}$ and $\mathrm{T}_{4}(16.04$ and 15.16), whereas the minimum number was recorded from $\mathrm{T}_{0}(14.18)$ which was statistically similar with $\mathrm{T}_{2}$ and $\mathrm{T}_{3}(15.06$ and 15.43 , respectively). It was revealed that all chemical fertilizer as recommended dose produced maximum number of spikelets spike $^{-1}$ but combination of manure with chemical fertilizers gave the similar results.

The longest spike was observed in $T_{1}(19.86 \mathrm{~cm})$, which was statistically similar with $\mathrm{T}_{8}, \mathrm{~T}_{9}, \mathrm{~T}_{7}, \mathrm{~T}_{6}, \mathrm{~T}_{5}$ and $\mathrm{T}_{4}(19.52 \mathrm{~cm}, 18.60 \mathrm{~cm}, 17.89 \mathrm{~cm}, 17.84 \mathrm{~cm}$, $17.77 \mathrm{~cm}$ and $16.32 \mathrm{~cm}$, respectively) and closely followed by $\mathrm{T}_{3}$ and $\mathrm{T}_{2}(16.06$ and $15.91 \mathrm{~cm}$, respectively), again the shortest spike was recorded from $\mathrm{T}_{0}(14.33 \mathrm{~cm})$. The maximum number of spikes $\mathrm{m}^{-2}$ was obtained from $\mathrm{T}_{1}$ (204.67), which was statistically similar with $\mathrm{T}_{8}, \mathrm{~T}_{7}, \mathrm{~T}_{9}, \mathrm{~T}_{6}, \mathrm{~T}_{5}$ and $\mathrm{T}_{4}$ (203.00, 198.00, 192.00, 186.67, 179.67 and 162.67, respectively) and closely followed by $\mathrm{T}_{3}$ (148.67), while the minimum number was recorded from $\mathrm{T}_{0}$ (121.33), which was statistically similar with $\mathrm{T}_{2}$ (144.33). Application of all chemical fertilizer as recommended dose ensured the macro and micro nutrients for the vegetative growth of the wheat that leads to the optimum reproductive growth and the ultimate results was the maximum number of tillers $\mathrm{m}^{-2}$ as well as maximum number of spikes $\mathrm{m}^{-2}$. Combination of cowdung, compost and chemical fertilizers in half recommended doses of chemical fertilizers also created a favorable condition for the growth and development of wheat plant for that combination of cowdung, compost and half chemical fertilizers gave the similar results.

Table 3. Effect of chemical and organic fertilizers and their combinations on number of plants $\mathrm{m}^{-2}$, number of spikes plant $^{-1}$, spike length, number of spikelets spike ${ }^{-1}$ and spike $\mathrm{m}^{-2}$ of wheat

\begin{tabular}{|c|c|c|c|c|c|}
\hline Treatment & Number of plants $\mathrm{m}^{-2}$ & $\begin{array}{c}\text { Number of spikes } \\
\text { plant }^{-1}\end{array}$ & Spike length $(\mathrm{cm})$ & $\begin{array}{l}\text { Number of spikelets } \\
\text { spike }^{-1}\end{array}$ & Number of spike $\mathrm{m}^{-2}$ \\
\hline $\mathrm{T}_{0}$ & $32.67 \mathrm{c}$ & $3.73 \mathrm{~d}$ & $14.33 \mathrm{c}$ & $14.18 \mathrm{~d}$ & $121.33 \mathrm{~d}$ \\
\hline $\mathrm{T}_{1}$ & $45.33 \mathrm{a}$ & $4.61 \mathrm{a}$ & $19.86 \mathrm{a}$ & $20.33 \mathrm{a}$ & $204.67 \mathrm{a}$ \\
\hline $\mathrm{T}_{2}$ & $37.67 \mathrm{bc}$ & $3.86 \mathrm{~cd}$ & $15.91 \mathrm{bc}$ & $15.06 \mathrm{~cd}$ & $144.33 \mathrm{~cd}$ \\
\hline $\mathrm{T}_{3}$ & $39.67 \mathrm{ab}$ & $3.74 \mathrm{~d}$ & $16.06 \mathrm{bc}$ & $15.16 \mathrm{~cd}$ & $148.67 \mathrm{~b}-\mathrm{d}$ \\
\hline $\mathrm{T}_{4}$ & $41.00 \mathrm{ab}$ & $3.95 \mathrm{~b}-\mathrm{d}$ & $16.32 \mathrm{a}-\mathrm{c}$ & $15.43 \mathrm{~b}-\mathrm{d}$ & $162.67 \mathrm{a}-\mathrm{d}$ \\
\hline $\mathrm{T}_{5}$ & $42.33 \mathrm{ab}$ & $4.24 \mathrm{a}-\mathrm{d}$ & $17.77 \mathrm{a}-\mathrm{c}$ & $16.04 \mathrm{~b}-\mathrm{d}$ & $179.67 \mathrm{a}-\mathrm{c}$ \\
\hline $\mathrm{T}_{6}$ & $43.33 \mathrm{ab}$ & $4.29 \mathrm{a}-\mathrm{d}$ & $17.84 \mathrm{a}-\mathrm{c}$ & $17.88 \mathrm{a}-\mathrm{d}$ & $186.67 \mathrm{a}-\mathrm{c}$ \\
\hline $\mathrm{T}_{7}$ & $42.00 \mathrm{ab}$ & $4.45 \mathrm{a}-\mathrm{c}$ & $17.89 \mathrm{a}-\mathrm{c}$ & $17.50 \mathrm{a}-\mathrm{d}$ & $198.00 \mathrm{a}$ \\
\hline $\mathrm{T}_{8}$ & $45.00 \mathrm{ab}$ & $4.50 \mathrm{ab}$ & $19.52 \mathrm{ab}$ & $19.07 \mathrm{ab}$ & $203.00 \mathrm{a}$ \\
\hline $\mathrm{T}_{9}$ & $43.67 \mathrm{ab}$ & $4.40 \mathrm{a}-\mathrm{c}$ & $18.60 \mathrm{ab}$ & $18.33 \mathrm{a}-\mathrm{c}$ & $192.00 \mathrm{ab}$ \\
\hline SE & 2.23 & 0.180 & 1.052 & 1.121 & 4.931 \\
\hline $\mathrm{CV}(\%)$ & 9.35 & 7.46 & 10.49 & 11.49 & 13.79 \\
\hline
\end{tabular}

In a column, means having similar letter(s) are statistically similar and those having dissimilar letter(s) differ significantly as per 0.05 level of significance. $\mathrm{CV}=\mathrm{Co}$-efficient of Variance. 
Weight of 1000 seeds, grain yield, straw yield, and biological yield and harvest index varied significantly due to different chemical and organic fertilizers and their combinations (Table 4). The highest weight of 1000 seeds was recorded from $\mathrm{T}_{1}(49.06 \mathrm{~g})$, which was statistically similar with $\mathrm{T}_{8}, \mathrm{~T}_{9}, \mathrm{~T}_{7}, \mathrm{~T}_{6}, \mathrm{~T}_{5}, \mathrm{~T}_{4}, \mathrm{~T}_{3}$ and $\mathrm{T}_{2}$ (respectively for $48.23 \mathrm{~g}, 47.42 \mathrm{~g}, 47.12 \mathrm{~g}$, $47.03 \mathrm{~g}, 45.62 \mathrm{~g}, 44.23 \mathrm{~g}, 43.78 \mathrm{~g}$ and $43.42 \mathrm{~g}$ ) and the lowest weight was recorded from $\mathrm{T}_{0}(39.48 \mathrm{~g})$ (Figure 4). It was revealed that all chemical fertilizer as recommended dose gave the highest weight of 1000 seeds. The highest yield was obtained from $T_{1}$ $\left(3.71 \mathrm{t} \mathrm{ha}^{-1}\right)$, which was statistically similar with $\mathrm{T}_{8}$, $\mathrm{T}_{9}$ and $\mathrm{T}_{7}$ (respectively for $3.66 \mathrm{tha}^{-1}, 3.51 \mathrm{t} \mathrm{ha}^{-1}$ and $\left.3.38 \mathrm{t} \mathrm{ha}^{-1}\right)$ and closely followed by $\mathrm{T}_{6}$ and $\mathrm{T}_{5},(3.22 \mathrm{t}$ $\mathrm{ha}^{-1}$ and $3.17 \mathrm{t} \mathrm{ha}^{-1}$, respectively). On the other hand, the lowest yield was found in $\mathrm{T}_{0}\left(2.06 \mathrm{tha}^{-1}\right)$. Ahmed and Hossain (1992) reported that chemical and organic fertilizer, the major essential plant nutrient, plays an important role in producing higher grain yield of wheat. The result was consistence with the findings of Baron et al. (1995) who reported positive influence of the addition of organic matter not only on soil properties but also on the mineral nutrient of plants and yield. The highest straw yield was observed in $\mathrm{T}_{1}\left(5.78 \mathrm{t} \mathrm{ha}^{-1}\right)$, which was statistically at per with $\mathrm{T}_{9}, \mathrm{~T}_{8}, \mathrm{~T}_{7}, \mathrm{~T}_{6}, \mathrm{~T}_{5}$ and $\mathrm{T}_{4}\left(5.72 \mathrm{tha}^{-1}, 5.65 \mathrm{t}\right.$ $\mathrm{ha}^{-1}, 5.61 \mathrm{tha}^{-1}, 5.45 \mathrm{tha}^{-1}, 5.41 \mathrm{tha}^{-1}$ and $5.16 \mathrm{t} \mathrm{ha}^{-1}$, respectively) and closely followed by $\mathrm{T}_{3}$ and $\mathrm{T}_{2}$ (4.93 $\mathrm{t} \mathrm{ha} \mathrm{a}^{-1}$ and $4.81 \mathrm{t} \mathrm{ha}^{-1}$, respectively). Again the lowest yield was recorded from $\mathrm{T}_{0}\left(4.49 \mathrm{tha}^{-1}\right)$.

The highest biological yield was found in $\mathrm{T}_{1}(9.49 \mathrm{t}$ $\mathrm{ha}^{-1}$ ), which was statistically similar with $\mathrm{T}_{8}, \mathrm{~T}_{9}$ and $\mathrm{T}_{7}$ (9.31 tha $\mathrm{th}^{-1}, 9.23 \mathrm{tha}^{-1}$ and $8.99 \mathrm{tha}^{-1}$, respectively) and was closely followed by $\mathrm{T}_{6}\left(8.67 \mathrm{t} \mathrm{ha}^{-1}\right)$ and that of the lowest $6.54 \mathrm{t} \mathrm{ha}^{-1}$ from $\mathrm{T}_{0}$. Application of all chemical fertilizer in recommended doses ensured the essential macro and micro nutrients for the vegetative and reproductive growth of wheat and the ultimate results were the highest grain and straw yield as well as maximum biological yield. Combination of cowdung, compost and chemical fertilizers half in recommended doses also created a favorable condition for the growth and development of wheat plant for that combination of cowdung, compost and half chemical fertilizers also gave the similar results. The highest harvest index was recorded from $T_{8}$ (39.35\%), which was similar with $\mathrm{T}_{1}, \mathrm{~T}_{2}, \mathrm{~T}_{3}, \mathrm{~T}_{9}, \mathrm{~T}_{4}$, $\mathrm{T}_{7}, \mathrm{~T}_{6}$ and $\mathrm{T}_{5}(39.21 \%, 38.51 \%, 38.25 \%, 38.01 \%$, $37.66 \%, 37.59 \%, 37.15 \%$ and $36.92 \%$, respectively) and the lowest harvest index was recorded from $\mathrm{T}_{0}$ $(31.49 \%)$.

Table 4. Effect of chemical and organic fertilizers and their combinations on weight of 1000 seeds, grain, straw \& biological yield and harvest index of wheat

\begin{tabular}{|c|c|c|c|c|c|}
\hline Treatment & $\begin{array}{l}\text { Weight of } 1000 \\
\text { seeds }(\mathrm{g})\end{array}$ & $\begin{array}{c}\text { Grain yield } \\
\left(\mathrm{t} \mathrm{ha}^{-1}\right)\end{array}$ & $\begin{array}{c}\text { Straw yield } \\
\left(\mathrm{t} \mathrm{ha}^{-1}\right)\end{array}$ & $\begin{array}{c}\text { Biological yield } \\
\left.h^{-1}\right)\end{array}$ & Harvest index (\%) \\
\hline $\mathrm{T}_{0}$ & $39.48 \mathrm{~b}$ & $2.06 \mathrm{~d}$ & $4.49 \mathrm{c}$ & $6.54 \mathrm{f}$ & $31.49 \mathrm{~b}$ \\
\hline $\mathrm{T}_{1}$ & $49.06 \mathrm{a}$ & $3.71 \mathrm{a}$ & $5.78 \mathrm{a}$ & $9.49 \mathrm{a}$ & $39.21 \mathrm{a}$ \\
\hline $\mathrm{T}_{2}$ & $43.42 \mathrm{ab}$ & $3.03 \mathrm{c}$ & $4.81 \mathrm{bc}$ & $7.84 \mathrm{e}$ & $38.51 \mathrm{a}$ \\
\hline $\mathrm{T}_{3}$ & $43.78 \mathrm{ab}$ & $3.05 \mathrm{c}$ & $4.93 \mathrm{bc}$ & $7.98 \mathrm{de}$ & $38.25 \mathrm{a}$ \\
\hline $\mathrm{T}_{4}$ & $44.23 \mathrm{ab}$ & $3.11 \mathrm{c}$ & $5.16 \mathrm{ab}$ & $8.27 \mathrm{de}$ & $37.66 \mathrm{a}$ \\
\hline $\mathrm{T}_{5}$ & $45.62 \mathrm{a}$ & $3.17 \mathrm{bc}$ & $5.41 \mathrm{ab}$ & $8.58 \mathrm{~cd}$ & $36.92 \mathrm{a}$ \\
\hline $\mathrm{T}_{6}$ & $47.03 \mathrm{a}$ & $3.22 \mathrm{bc}$ & $5.45 \mathrm{ab}$ & $8.67 \mathrm{~b}-\mathrm{d}$ & $37.15 \mathrm{a}$ \\
\hline $\mathrm{T}_{7}$ & $47.12 \mathrm{a}$ & $3.38 \mathrm{a}-\mathrm{c}$ & $5.61 \mathrm{a}$ & $8.99 \mathrm{a}-\mathrm{c}$ & $37.59 \mathrm{a}$ \\
\hline $\mathrm{T}_{8}$ & $48.23 \mathrm{a}$ & $3.66 \mathrm{ab}$ & $5.65 \mathrm{a}$ & $9.31 \mathrm{ab}$ & $39.35 \mathrm{a}$ \\
\hline $\mathrm{T}_{9}$ & $47.42 \mathrm{a}$ & $3.51 \mathrm{a}-\mathrm{c}$ & $5.72 \mathrm{a}$ & $9.23 \mathrm{a}-\mathrm{c}$ & $38.01 \mathrm{a}$ \\
\hline SE & 2.081 & 0.151 & 0.206 & 0.220 & 3.198 \\
\hline $\mathrm{CV}(\%)$ & 6.89 & 8.14 & 6.73 & 7.49 & 5.94 \\
\hline
\end{tabular}

In a column, means having similar letter(s) are statistically similar and those having dissimilar letter(s) differ significantly as per 0.05 level of significance. $\mathrm{CV}=\mathrm{Co}$-efficient of Variance.

\section{References}

Aga, F. A.; Singh, J. K.; Singh, D. K. and Peer, F. A. 2004. Effect of different levels of compost on growth and yield of rice. Environ. Ecol., 22(2): 353-356.

Ahmed, M. and Hossain, S. M. A. 1992. Effect of seed rate, nitrogen ferilization and time of harvest on the seed yield of wheat. Bangladesh Agron. J., 4 (1\&2):35-34.

BARI (Bangladesh Agricultural Research Institute). 2006. Wheat production technology (A booklet in Bengali), Wheat Res. Centre, Bangladesh Agril. Res. Inst. Nashipur, Dinajpur. pp. 18-19. 
Baron, R.; Benitez, I. C. and Gonzalez, J. L. 1995. The influence of organic matter additions in wheat cultivation. Agronchimica., 39(5):280290.

BBS (Bangladesh Bureau of Statistics). 2010. Statistical Pocket Book of Bangladesh. Bangladesh Bureau of Statitics Division, Ministry of Planning. Goventment People's Republic of Bangladesh. pp. 194.

Davarynejad, G. H.; Haghnia, G. H. and Lakzian, A. 2004. Effect of municipal compost in combination with chemical fertilizers and manure on growth and yield of wheat. Agril. Sci. Tech., 18(1): 101-108.

Dubin, H. J. and M. V. Ginkel. 1991. The status of wheat diseases and disease research in warmer areas. In D. A. Saunders ed., Wheat for the non traditional warm areas, Mexico D. F. CIMMYT. pp. 125-145.

FAO (Food and Agricultural Organization). 2010. Production Year Book. FAO. UN. Italy. Rome. p. 95-98.

FAO (Food and Agriculture Organization). 2000. Production Yearbook. Food and Agriculture
Organization of the United Nations, Rome, Italy. p. 62.

Gomez, K. A. and Gomez, A. A. 1984. Statistical Procedures for Agricultural Research. $2^{\text {nd }}$ Edn. John Wiley and Sons. New York. Chichester, Brisbane, Toronto, Singapore. p. 680.

Majumder, A. R. 1991. Assessment of yield loss caused by common root rot (Bipolaris sorokiniana) in wheat a cultivar in Queensland. Australian. J. Agril. Res., (Australia). 13(3): 143-151.

Razzaque, M. A.; Sufian, M. A. and Badaruddin, M. 1992. Wheat in the national economy of Bangladesh. Proc. Adv. Crop. Sci. Biennial Conf. Crop Sci., Bangladesh. BAU, Mymensingh, 13-25.

Singh, C. P. J. and Singh, S. S. 2000. Studies on the growth and yield parameters of wheat (Triticum aestivum L.) to urea and sludge based compost application. Madras Agril. J. 87(10-12): 727-728.

Tamaki, M.; Itani, T. and Nakanu, H. 2002. Effect of organic farming on the growth and yield of rice. Japanese J. Crop Sci., 71(4): 439-445. 